\title{
カオリン素地の焼き締り過程に関する研究
}

\author{
浜 野 健 也・李応相 \\ (東京工業大学工業材料研究所)
}

\section{Studies on the Densification Process of Kaolin Bodies}

\author{
By \\ Kenya HAMANO and Eung Sang LEE \\ (Reseach Laboratory of Engineering Materials, Tokyo Institute of Technology, Tokyo)
}

\begin{abstract}
Densification processes and microstructural changes of kaolin bodies during firing were examined and their co-relations were discussed.

From the results of the firing shrinkage, bulk density and apparent porosity measurements, following results were obtained. Degree of densification increased with the temperature. The longer the grinding time of the kaolin, the lower the densification of the bodies when fired at $1000^{\circ} \mathrm{C}$. However, when fired at temperatures higher than $1100^{\circ} \mathrm{C}$, the effect of grinding time on the densification of kaolin resulted inversely.

Shrinkage behaviours were also examined kinematically, and the following results were inferred. The kaolin body shrank at about $500^{\circ} \mathrm{C}, 900^{\circ} \mathrm{C}$ and $1100^{\circ} \mathrm{C}$. Shrinkage occurred at about $900^{\circ} \mathrm{C}$ might be due to the diffusion sintering process of metakaolin grains. Shrinkage occurred at slightly lower temperatures than $1100^{\circ} \mathrm{C}$ might be attributed to the viscous flow mechanism and partly diffusion process in the spinel intermediate phase.

Microstructural changes of the fired bodies were also examined by means of X-ray diffraction, polarizing microscope and scanning electron microscope. Further, it was shown that the densification processes and accompanied phenomena of the fired bodies were clearly explained by these microstructural observations.
\end{abstract}

[Received July 12, 1971]

\section{1. 緒言}

酸化物などを加熱した場合の燒き締り，特に焼結の過 程については最近多くの研究が行なわれ，次第に明らか にされてきつつある。しかしこの場合にも, 液相の共存 した場合の焼結過程については, まだ研究が始められた ばかりの段階のように思われる。一方，実際にセラミッ ク工業で使われている原料の多くは, 天然の，上り複雑 なものが多いので, このようなものについての加熱過程

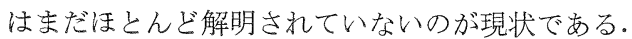

本研究はこのような観点から, セラミック工業の基本 的な原料の一つであるカオリンについて，これを加熱し た場合の焼き締りの状態を再検討し，セラミック素地の 焼成過程を定量化する一資料を得ようとしたものであ る。

\section{2. 使用原料および前処理}

試料として, わが国の陶磁器業界で広く使われている 韓国河東産カオリン水箕物を使用した。この試料は, 粉 末X線回折の結果，ほとんど加水八ロイサイトで，わず かに石英, 長石をともなうものである.これらの石英や
長石は，さらに水筙を試みたが除去することができなか ったので，そのまま実験に使用した。この試料の示差熱 分析結果は図-1, また化学分析值は表-1の通りである.

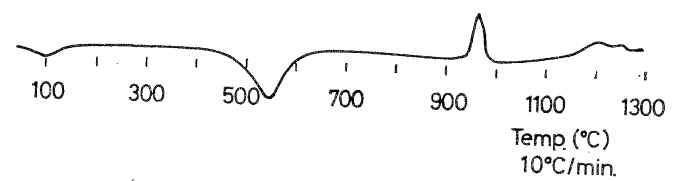

Fig. 1. DTA curve of korean kaolin.

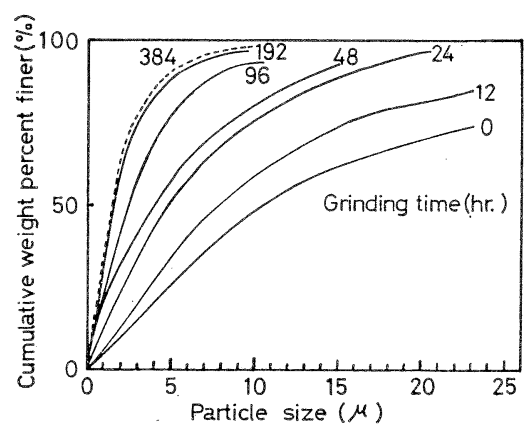

Fig. 2. Particle size distribution curves of the kaolin. 
Table 1. Chemical composition of korean kaolin (Hadong area) elutriated. (\%)

$\begin{array}{llllllll}\mathrm{SiO}_{2} & \mathrm{TiO}_{2} & \mathrm{Al}_{2} \mathrm{O}_{3} & \mathrm{Fe}_{2} \mathrm{O}_{3} & \mathrm{MnO} \mathrm{CaO} \mathrm{MgO} \mathrm{Na} & \mathrm{Na} \mathrm{K}_{2} \mathrm{O} & \mathrm{Ig} & \end{array}$

$\begin{array}{llllllllll}45.81 & 0.09 & 38.45 & 0.70 & \text { tr. } & 0.35 & 0.25 & 1.14 & 13.21\end{array}$

試料カオリンの粒度は島津製自動粒度測定器で測定し た。その結果を図-2 に併記したが，5 以下 $25 \%, 20$ $\mu$ 以下 $70 \%$ 位で相当に粗粒である. 燒き締りは粒度に よっても影響されると考えられるので，さらにこれをア ルミナ製ポットミルで $12 ， 24 ， 48 ， 96 ， 192$ および 384 hrs 湿式粉砕して試料とした. 粉砕後の試料の粒度分布 測定結果も図-2 に示したが，粉砕時間の長いものほど 粒子が細かくなっていることがわかる。これらの試料は アルミナ製ポットミルで粉砕しているため, $\mathrm{Al}_{2} \mathrm{O}_{3}$ が混 入している可能性があるので, 各試料の $\mathrm{Al}$ 量を蛍光 $\mathrm{X}$ 線分析してみた。困-3 はその結果を示したものである

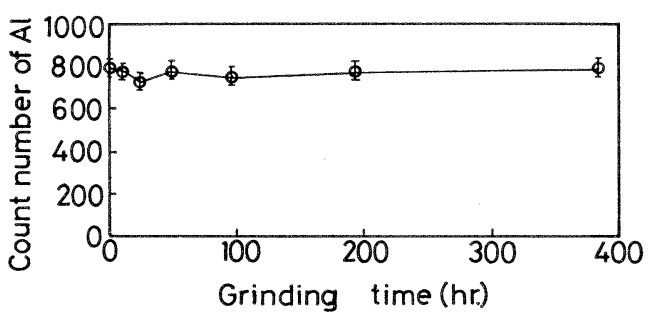

Fig. 3. Al content of ground kaolin by X-ray spectrometer vs. grinding time.

が, $384 \mathrm{hrs}$ 粉砕後の試料でも, $\mathrm{Al}$ 量は測定值のバラツ キ範囲内の変化を示すのみで, ほとんど増加している様 子はなく, 結局ポットミルからの $\mathrm{Al}_{2} \mathrm{O}_{3}$ の混入は無視 できるよらである。

これらのカオリン試料をそれぞれ単味で 2 種類の試験 片に成形した。1つは金型を用い，油圧プレスで $5 \times 10$ $\times 80 \mathrm{~mm}$ の試験片（試験片（Ｉ）と呼ぶ）に $800 \mathrm{~kg} / \mathrm{cm}^{2}$ の圧力で乾式成形した. も5 1 つはベークライト内張り 型を用いて，まず油圧ハンドプレスで $5 \times 5 \times 40 \mathrm{~mm}$ の 試験片に $300 \mathrm{~kg} / \mathrm{cm}^{2}$ の圧力で乾式成形した後, さらに $800 \mathrm{~kg} / \mathrm{cm}^{2}$ の圧力でハイドロスタティックプレス成形 した（試験片（II）と呼ぶ).

\section{3. カオリン試験片の焼き締り}

まずこれらカオリン試料の焼き締り状態を概略検討す るため, 試験片の焼成収縮率, 嵩比重, 見掛気孔率を測 定した. 試験片（I）を電気炉中で，加熱速度 $6^{\circ} \mathrm{C} / \mathrm{min}$ で $1000^{\circ} \sim 1400^{\circ} \mathrm{C}$ の所定温度に加熱し，それぞれ $2 \mathrm{hrs}$ 保持した後，炉冷して測定試験片とした. 試験片の長さ 方向について測定した燒成収縮率の結果を図-4に示す. 值は 5 本の試験片についての結果の平均值である. 図か ら焼成収縮率は焼成温度の上昇とともに増大することが わかる.しかしカオリンの粉砕時間が $48 \mathrm{hrs}$ 以上にな

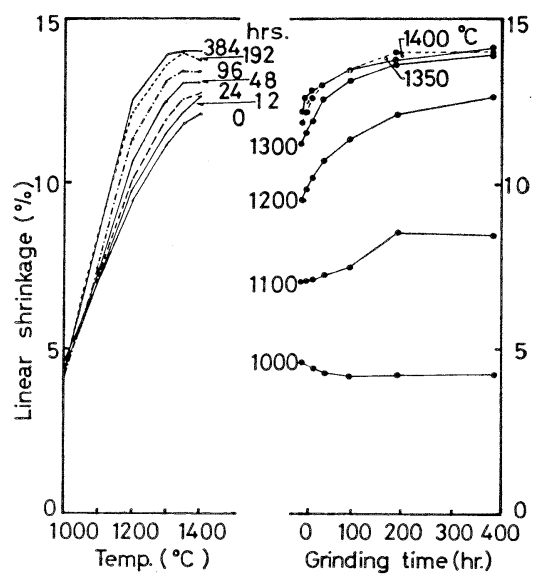

Fig. 4. Linear shrinkage of the fired kaolin bodies.

ると, $1350^{\circ} \mathrm{C}$ 位で収縮率はほぼ平衡に達し, それ以上 温度が高くなってもほとんど増大しないか，逆に幾分低 下するよらになる。 また焼成温度が $1000^{\circ} \mathrm{C}$ の場合には 粉砕時間の長くなるほど焼成収縮率は，わずかに減少す るが，少なくとも $1100^{\circ} \mathrm{C}$ 以上では, 粉砕時間の長くな るほど収縮率が増大することがわかり， $1000^{\circ} \mathrm{C}$ 付近の 温度を境にして焼き締りに対する粉砕の効果が異なるこ とがわかる。

同しようにして得られた嵩比重の測定結果は図-5の

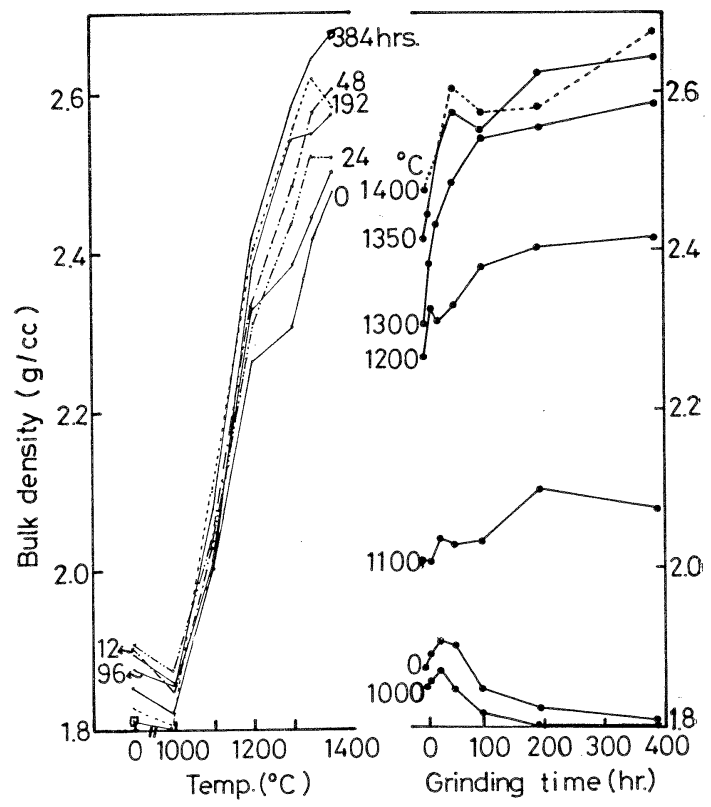

Fig. 5. Bulk densities of the fired kaolin bodies.

通りである。この值は 5 ケの測定值のらち, 最小值を除 いた残り 4 ケの平均である。未焼成試験片の蒿比重は力 オリンの粉砕時間とともに大きくなり，24hrs 粉砕のも ので最大となった後, さらに粉砕時間が長くなると次第 に小さくなり，充填が悪くなることを示している.1000 
${ }^{\circ} \mathrm{C}$ 焼成の場合にも同じ傾向を示すが， $1100^{\circ} \mathrm{C}$ 以上にな ると，粉砕時間の長くなるほど訔比重は顕著に増大する ようになる。

$1000^{\circ} \mathrm{C}$ 焼成の試験片の訔比重が，未焼成のものにく らべ幾分低下しているが，これはカオリンの脱水による ものである． $1000^{\circ} \mathrm{C}$ 以上になると温度の上昇とともに 訔比重々急速に增大寸る。焼成収縮率の場合と異なり， 高温度になっても高比重の増大が止まる傾向は余り顕著 でなかった。

図-6 は見掛気孔率の測定結果をまとめたもので，值 は 5 ケの測定值から最大值を除いた，残り 4 ケの平均で ある。気孔率は温度上昇とともに急激に規則正しく減少
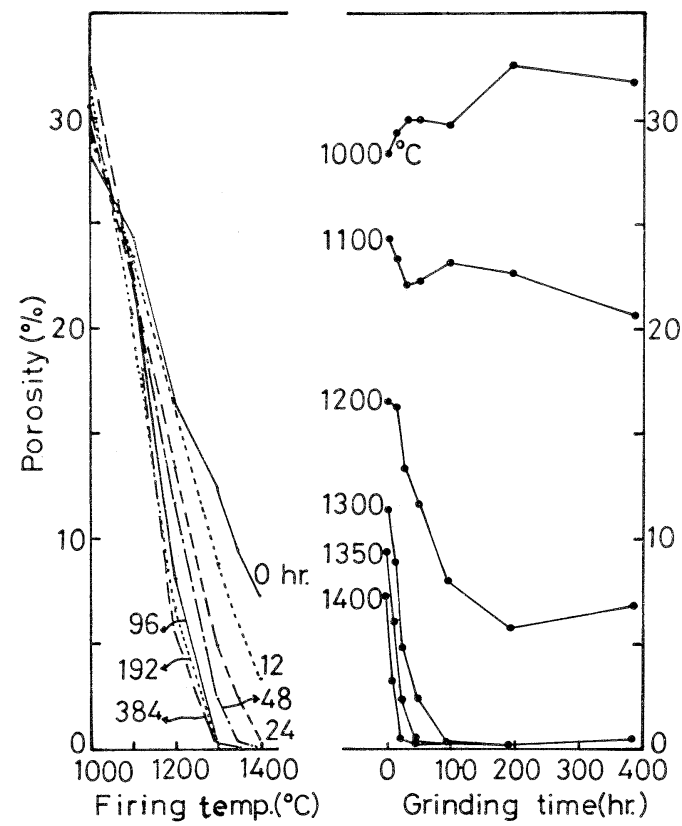

Fig. 6. Apparent porosity of the fired kaolin bodies.

する.この減少の傾向は粉砕時間の長いカオリンほど急 激である。 また粉砕時間 $48 \mathrm{hrs}$ の場合は $1350^{\circ} \sim 1400$ ${ }^{\circ} \mathrm{C}, 96 \mathrm{hrs}$ では $1300^{\circ} \sim 1350^{\circ} \mathrm{C}, 192 \mathrm{hrs}$ 以上では 1300 ${ }^{\circ} \mathrm{C}$ の焼成で, 結局粉砕時間の長くなるほど低温度で, 見掛気孔率は注ぼ 0 になることがわかる，1000 ${ }^{\circ} \mathrm{C}$ で焼 成した場合には粉硒時間の長くなるほど気孔率は大きく なる。しかし $1100^{\circ} \mathrm{C}$ 以上で焼成した場合は逆に粉砕時 閏の長いほど気孔率は低下する。

以上の焼成収縮率，嵩比重および見掛気孔率の測定結 果から粉砕時間を変えた場合のカオリン素地の焼き締り をまとめてみると, $1000^{\circ} \mathrm{C}$ 焼成の場合には，粉碎時間 の長いもの洼ど焼成収縮が小さく，見掛気孔率も大きく なり，明らかに焼き締りが阻害されていることがわかる。 $1100^{\circ} \mathrm{C}$ 以上になると焼成温度の上昇とともに収縮率も 嵩比重も急速に増大し，また見掛気孔率も著るしく減少 し，焼き締りが急速に進行することがわかる．またこの
温度範囲になると，粉砕時間の長いカオリンほど焼き締 りが急速に進行し，同時に緻密化もより大きくなる，そ の結果 $48 \mathrm{hrs}$ 以上粉砕したカオリンの成形試験片は, $1350^{\circ} \mathrm{C}$ 以下の温度でほぼ見掛気孔率 0 となり, 収縮率 も平衡值に達する傾向を示すようになる。

\section{4. カオリン素地焼成物の組成鉱物}

素地の焼き締り状態についてはほぼ明らかにできたの で，次にこのような焼き締り状態の変化を生ずる原因を 究明するため，まず焼成素地の組成鉱物を粉末 X線回折 法で検討した．カオリン鉱物を加熱した場合の変化につ いてはすでに多数の研究が行なわれているが(1) 8)，今日 では，ほぼ次のように変化すると認められている7),8).

$$
\begin{aligned}
& \mathrm{Al}_{2} \mathrm{O}_{3} \cdot 2 \mathrm{SiO}_{2} \cdot 2 \mathrm{H}_{2} \mathrm{O} \stackrel{\text { 約 } 500^{\circ} \mathrm{C}}{\longrightarrow} \mathrm{Al}_{2} \mathrm{O}_{3} \cdot 2 \mathrm{SiO}_{2}+2 \mathrm{H}_{2} \mathrm{O} \\
& \text { メタカオリン } \\
& 2\left(\mathrm{Al}_{2} \mathrm{O}_{3} \cdot 2 \mathrm{SiO}_{2}\right) \stackrel{\text { 約 } 925^{\circ} \mathrm{C}}{\longrightarrow} 2 \mathrm{Al}_{2} \mathrm{O}_{3} \cdot 3 \mathrm{SiO}_{2}+\mathrm{SiO}_{2} \\
& \text { アルミニウム・ンリコン・スピネル } \\
& 3\left(2 \mathrm{Al}_{2} \mathrm{O}_{3} \cdot 3 \mathrm{SiO}_{2}\right) \stackrel{1200^{\circ} \sim}{1400^{\circ} \mathrm{C}} \longrightarrow 2\left(3 \mathrm{Al}_{2} \mathrm{O}_{3} \cdot 2 \mathrm{SiO}_{2}\right)+\mathrm{SiO}_{2}
\end{aligned}
$$

綰局最後にはムライトとクリストバライトに変わる.

実際の焼成試験片の場合には如何なる組成鉱物が存在 しているかを検討するため，試験片（I）を前と同じ条 件で $700^{\circ} \sim 1400^{\circ} \mathrm{C}$ に焼成して粉末とし，X線回折を行 なった。さらに $1100^{\circ} \mathrm{C}$ 以上の試料については組成鉱物 の相対量比を検討するため $\mathrm{BaCO}_{3}$ を $10 \%$ ，内部㯲準 として添加して測定した。その結果認められた組成鉱物 は，不純物としてカオリン中に含まれていた微量の石英 と長石のほか, $900^{\circ} \sim 1100^{\circ} \mathrm{C}$ でスピネル型中間相鉱物, さらに高温度範囲でムライト，クリストバライトであ る. スピネル型鉱物は $900^{\circ} \mathrm{C}$ では極くわずかに認めら れるのみであるが， $1000^{\circ} \mathrm{C}$ では結晶相のほとんどを占

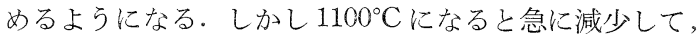
少量残存しているくらいになる。また例外もあるが，こ のスピネル鉱物は粉砕時間が $24,48 \mathrm{hrs}$ では $900^{\circ} \mathrm{C}$ で も相当量認められるが，それよりも粉砕時間が短かくて も長くても急激に少なくなる傾向を示している.

クリストバライトの，ピーク面積から算出した相対含 有量の変化は図-7 に示した通りである. クリストバラ イトは $1100^{\circ} \sim 1200^{\circ} \mathrm{C}$ で認められるようになり，1200 $\sim 1300^{\circ} \mathrm{C}$ では相当量存在するが， $1350^{\circ} \mathrm{C}$ になると急激 に減少し， $1400^{\circ} \mathrm{C}$ 焼成の素地中にほとんど認められな くなる。また大体の傾问として，粉砕時間の長いほどク リストバライトの生成量が多くなり，また生成温度もわ ずかではあるが低温度にずれてくることがわかる。

同じくピーク面積から算出したムライトの相詨含有量 は図-8のようである。ムライトは $1200^{\circ} \mathrm{C}$ 以上になる と認められるようになるが，それ以上焼成温度が高くな っても規則的な変化を示さず，少なくとも $1400^{\circ} \mathrm{C}$ まで 


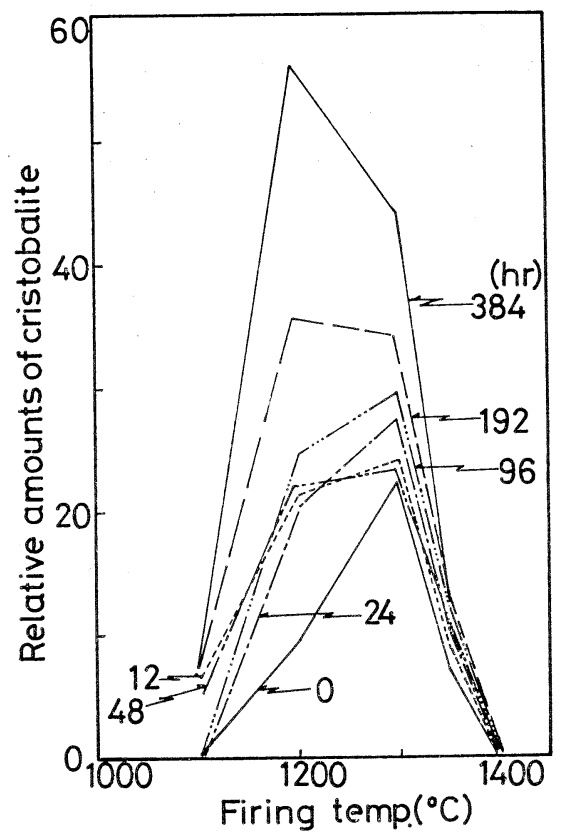

Fig. 7. Relative amounts of cristobalite in fired kaolin bodies.

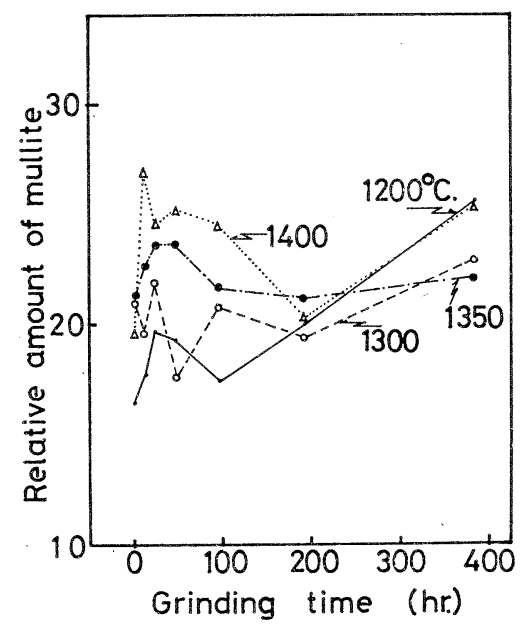

Fig. 8. Relative amount of mullite in fired kaolin bodies.

は認められる。また粉砕時間との間にも余り規則的な相 互関係が認められず，ただ $24 \mathrm{hrs}$ 粉研のものが幾分ム ライト量が多く，また $384 \mathrm{hrs}$ 粉砕のものでは焼成温度 の高くなるほどムライト量が減少する傾向があるようで ある。

以上の結果加ら，この試料の組成鉱物は，不純物とし て含まれている微量の石英, 長石のほか, 次のようなる のである. $900^{\circ} \mathrm{C}, 2 \mathrm{hrs}$ 焼成の試料中に一般には極く 少量認められるようになるスピネル型鉱物，このものは $1000^{\circ} \mathrm{C}$ で最も多くなるが, $1100^{\circ} \mathrm{C}$ になる 急減し， $1200^{\circ} \mathrm{C}$ では全く認められなくなる。スピネル型鉱物の
急減する $1100^{\circ} \sim 1200^{\circ} \mathrm{C}$ 付近からクリストバライトが認 められるよらになり，1200〜 $1300^{\circ} \mathrm{C}$ では相当に存在す るが， $1350^{\circ} \mathrm{C}$ になると急速に少なくなり，1400ㄷ では 全く認められなくなる.カオリンの粉砕時間の長いほど, クリストバライトの生成温度が低下し, 生成量も多くな る。また $1200^{\circ} \mathrm{C}$ 以上になると，ムライトも辣められる ようになるが，その生成量などは焼成温度やカオリンの 粉砕時間と余り規則的な関係を示さず,少なくとも 1400 ${ }^{\circ} \mathrm{C}$ でも同じくらい含まれている。

このように実験に使ったカオリン素站の組成鉱物の変 化は, Brindley ら ${ }^{7,8)}$ の述へているカオリナイトの加熱 変化とほぼ一致しているが， $1350^{\circ} \mathrm{C}$ 以上になるとクリ ストバライトが急減し， $1400^{\circ} \mathrm{C}$ になると全く認められ なくなる点は著しく異なっている.

\section{5. 焼き締り過程の速度論的検討}

以上でカオリン単味素地の焼き締りの傾向と, 焼成素 地の組成鉱物などが明らかになったので，次にこのよう な素地の焼き締りの過程を検討した。まず燒き締り過程 の概略を見当付けるため, 試験片（II）を用いて昇温速 度 $10^{\circ} \mathrm{C} / \mathrm{min}$ で熱膨脹収縮の測定を行なった。得られた 結果を困-9 に示す。カオリン試験片は $500^{\circ} \mathrm{C}$ 付近 (I), $900^{\circ} \mathrm{C}$ 付近 (II), $1100^{\circ} \mathrm{C}$ 付近 (III) と 3 段階に

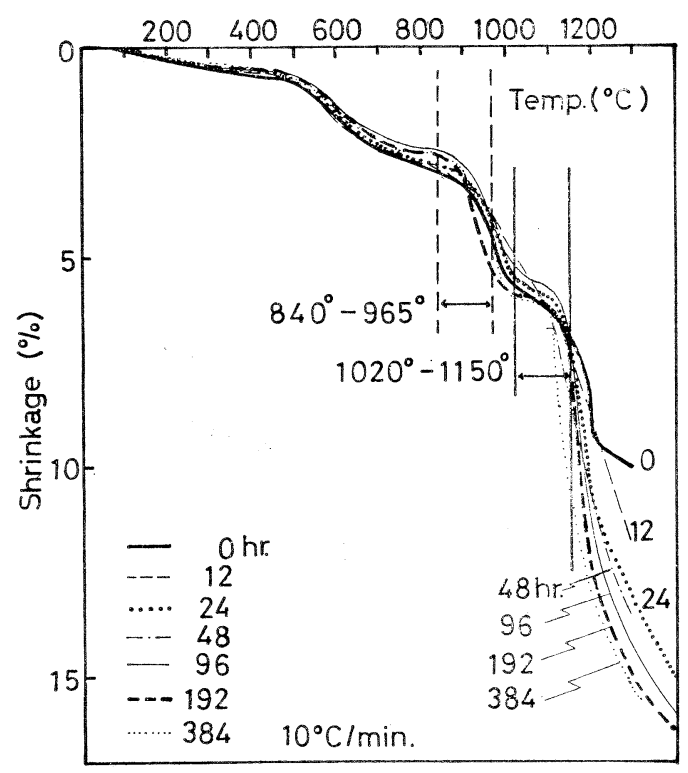

Fig. 9. Shrinkage curves of the kaolin bodies.

顕著な収縮を有する。これらの収縮に対する粉砕時間の 効果は概して不規則であるが, $1200^{\circ} \mathrm{C}$ 以上になると明ら かに粉砕時間の長いカオリンほど収縮摔が大きくなる。 3 段階に分かれた顕著な収縮のらち $500^{\circ} \mathrm{C}$ 们近の収縮 はカオリンの脱水に起因することが明らかなので検討を 省略し，残りの 2 段階の収縮に対して実験を行なった。 
このように何段階かに分れて収縮を起す試験片の収縮 を検討する場合, 各段階で起る収縮を他の段階での収縮 と区別して測定する必要がある. そのためには前の段階 で起る収縮を完全に終了させてから次の段階の収縮を測 定すればよい。予備実験から $500^{\circ} \mathrm{C}$ 付近から始まる(I) の収縮は $700^{\circ} \mathrm{C}$ で $2 \mathrm{hrs}$ 保つとほとんぞ終了し, 試験 片の長さは一定となり, また $900^{\circ} \mathrm{C}$ で始まる(II) の収 縮も $1000^{\circ} \mathrm{C}$ で $2 \mathrm{hrs}$ 保つとほとんど終了することがわ かったので, (II)の収縮を検討する試験片は予め $700^{\circ} \mathrm{C}$ で $2 \mathrm{hrs}$ また (III) の収縮を検討する試験片は $1000^{\circ} \mathrm{C}$ で 2 hrs 加熱してから使用することとした.

収縮過程は無荷重式の熱膨脹計 ${ }^{9}$ を使用して等温収縮 の測定によって検討した. (II) の収縮の検討には $840^{\circ}$ $\sim 965^{\circ} \mathrm{C}$, また (III) の収縮の検討には $1020^{\circ} \sim 1150^{\circ} \mathrm{C}$ の温度範囲を用い, 各 5 点の温度について測定した. 得 られた等温収縮曲線の一例を図-10 に示す。さらにこの

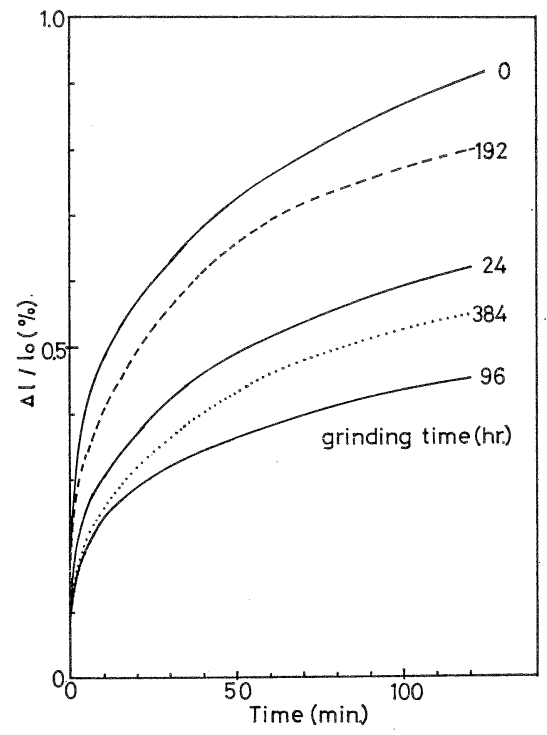

Fig. 10. Isothermal shrinkage curves of the kaolin bodies at $880^{\circ} \mathrm{C}$.

曲線に対し，時間と試験片の初期長さ $l_{0}$ に対する補正 を行なった後, 時間と収縮率との関係を両対数プロット すると図-11, 12 の例のような, いずれすほぼ良好な直 線関係を示す。図-11 は（II）の段階での結果であるが, この図から $840^{\circ} \sim 900^{\circ} \mathrm{C} く ら い の$ 範囲では直線の勾配は $0.29 \sim 0.22$ の範国に大りいちよらであるが， $920^{\circ} \mathrm{C}$ 以 上になると公配は次第に小さくなり, 収縮の過程が変化 してくることを推定させる。それ故この $840^{\circ} \sim 900^{\circ} \mathrm{C} の$ 温度範囲に対して, 直線の勾配加ら収縮速度定数 $B^{\prime}$ を 算出し，アレニウス・プロットすると図-13 のような直 線関係が得られる. この関係から (II) 段階での収縮過 程に対する見掛けの活性化エネルギ一值 $(E)$ と度数因 子 $(A)$ を算出し, カオリンの粉砕時間に対してプロッ

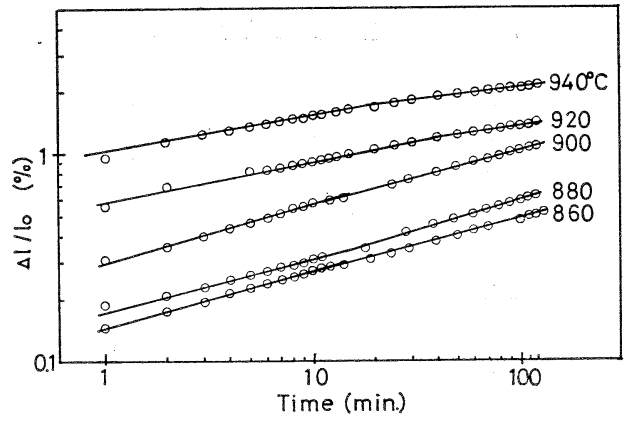

Fig. 11. $\log \left(\Delta l / l_{0}\right)$ vs. $\log$ (time) for ground kaolin body for $24 \mathrm{hrs}$.

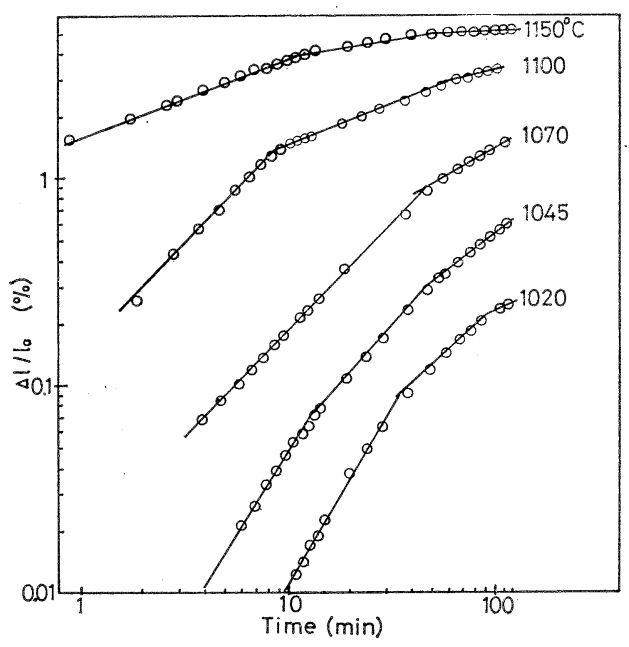

Fig. 12. Log $\left(\Delta l / l_{0}\right)$ vs. log (time) for ground kaolin body for $24 \mathrm{hrs}$.

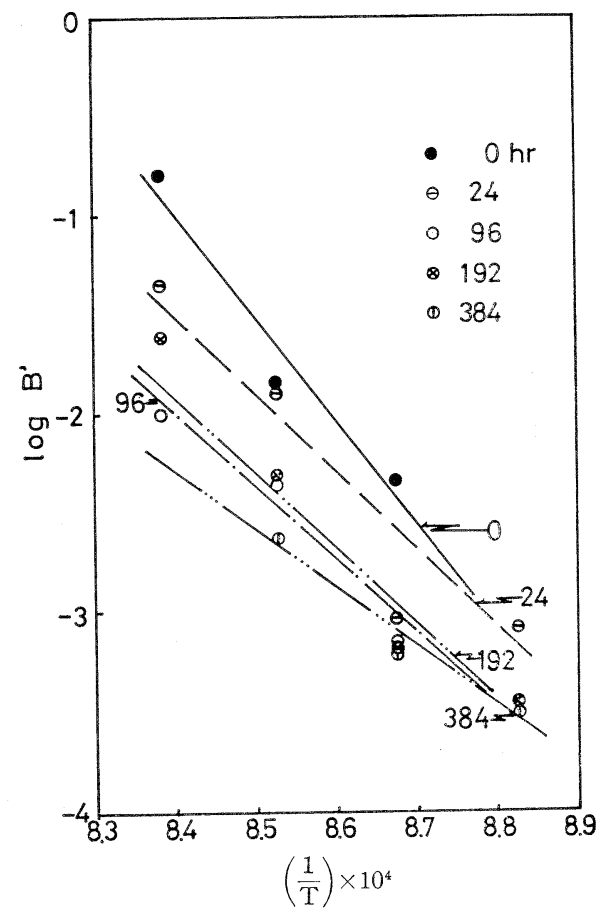

Fig. 13. Arrhenius plot (for $840^{\circ} \sim 900^{\circ} \mathrm{C}$ ). 


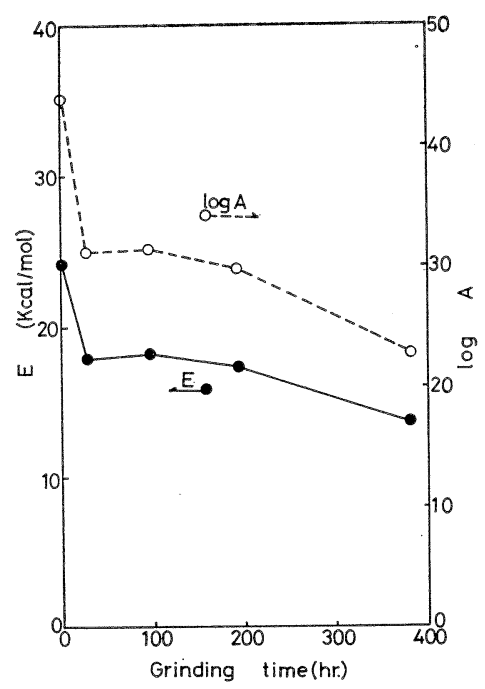

Fig. 14. Apparent activation energy and frequency factors for shrinkage occurred at about $900^{\circ} \mathrm{C}$ for kaolin bodies vs. grinding time.

トすると図-14 のようになる。これらの值はともに 24 hrs 粉砕で急に小さくなり, その後, 粉砕時間とともに 徐々に減少する傾向を示している。

図-12 は（III）の段階での収縮率と時間との両対数プ ロットであるが，この範囲の勾配は大部分 $1.0 \sim 1.3$ の 範囲に入るが, $384 \mathrm{hrs}$ 粉砕の場合のみは 0.7 前後と, 他の粉砕時間の場合と異なり小さな值となっている.こ れから前と同じようにして速度定数 $B^{\prime}$ を算出し，これ をアレニウス・プロットすると図-15 のような直線関倸 が得られる.この関倸から（III）の収縮過程に対する見 掛けの活性化エネルギ一值と度数因子を算出し，プロッ トすると図-16 のようになる．粉砕時間 $192 \mathrm{hrs}$ までは 規則的な傾向がみられず， $384 \mathrm{hrs}$ になると急に大きな 值を示すようになる。

以上の結果，カオリン素地の焼き締りは $500^{\circ} \mathrm{C}$ 付近の カオリンの脱水にともなうものにつづき, $900^{\circ} \mathrm{C}$ 付近と $1100^{\circ} \mathrm{C}$ 付近の 3 段階に分加秃て起ること, $900^{\circ} \mathrm{C}$ 付近 を中心とする収縮は等温収縮測定の結果，収縮率と時間 との両対数プロットが勾配 $0.29 \sim 0.22$ の直線関係を示 し, その勾配の大きさから，ほぼ粒界拡散と思われる拡 散焼結と推定され, また $1100^{\circ} \mathrm{C}$ 付近で起る収縮は, 同 じように収縮率と時間との両対数プロットが直線関係を 示すが，その值は 1.0 1.3くらいとなり，多分，粘性 流動機構による収縮であるうと推定される。しかし 384 hrs 粉砕の試料の場合のみは勾配が 0.7 と小さく, 粘性 流動機構のみではなく, 一部体積拡散による焼結機構も 重複して起っていることが推定される.さらに加熱收縮 曲線から $1200^{\circ} \mathrm{C}$ 以上になると明らかに粉砕時間の長い カオリンの方が収縮が大きくなることなども明らかにな った。

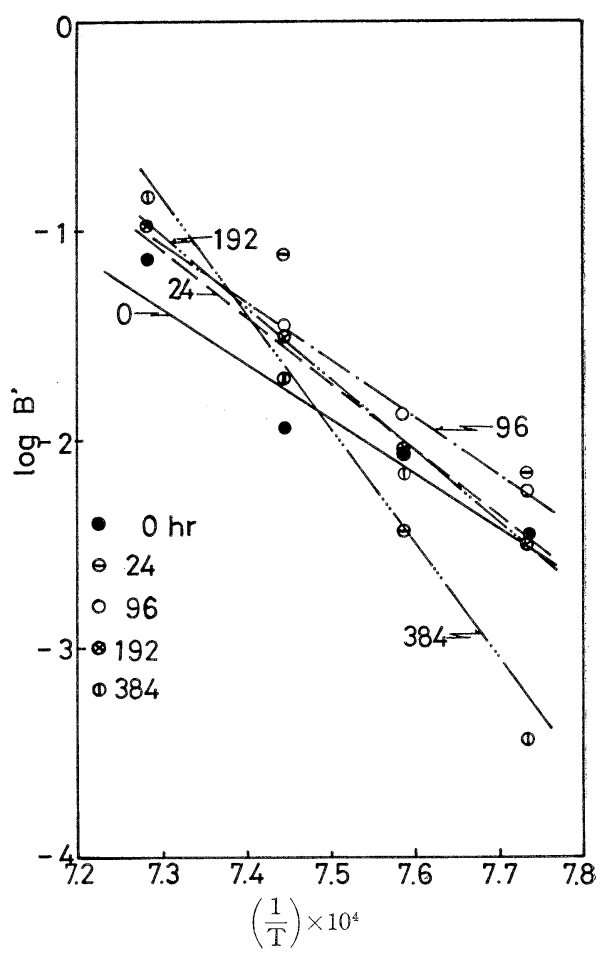

Fig. 15. Arrhenius plots (for $1020^{\circ} \sim 1100^{\circ} \mathrm{C}$ ).

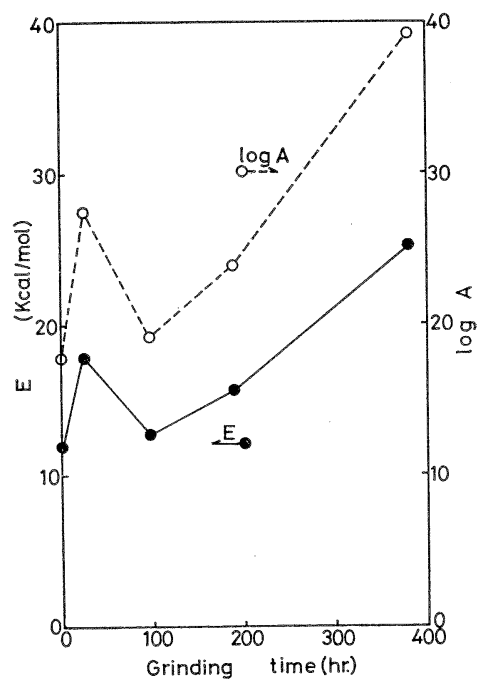

Fig. 16. Apparent activation energy and frequency factors for shrinkage occurred at about $1100^{\circ} \mathrm{C}$ for kaolin bodies vs. grinding time.

\section{6. 焼成試験片の偏光顕微鏡および走査型電子顕微鏡 観察}

以上の結果から明らかになった，カオリン素地の焼き 締り過程が温度範囲によって異なることの原因を究明 乙, さらに $1200^{\circ} \mathrm{C}$ 以上の高温度範囲で起る緻密化の過 程を検討するため, 各温度に焼成した試験片について偏 
光顕微鏡および走查型電子顕微鏡観察を行ない，その組 成鉣物や組織の変化を観察した。

\section{1 偏光顕微鏡観察}

観察は主として薄片について行なったが，一部粉末試 料についても観察した. 図-17,18,19 に顕微鏡写真の 一部を示す.

未粉砝カオリンの成形試験片の $700^{\circ} \mathrm{C}$ 焼成物では, カオリンは数ル大の単離したものもあるが, 多くは 5〜 $35 \mu$ 位の集束状の集合となり，まだ暗灰色から灰色位 の干涉色を保っている. この中に多くは数十 $\mu$, 時に数 百 $\mu$ 大の雲母状着色鉱物が少なからず分布し, さらに少 量であるが数〜数十 る、顕微鏡的にはまだ加熱による変化は認められない (図-17(a))，900 $\mathrm{C}$ になると全体に幾分干涉色が低下 し，またカオリン集団中の粒界や周囲などに極くわずか に低屈折率部分が生じる. $1000^{\circ} \mathrm{C}$ になるとマトリック ス部全体に点々と $0.5 \mu$ 大の少粒子状の低屈折率ガラス が生成し始める. カオリン部分* の干渉色は $1100^{\circ} \mathrm{C} に$

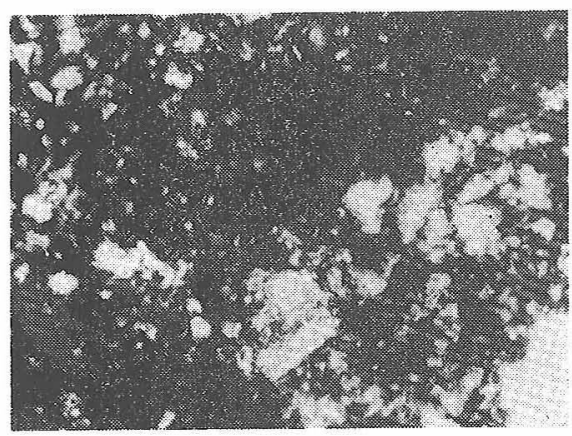

(a)

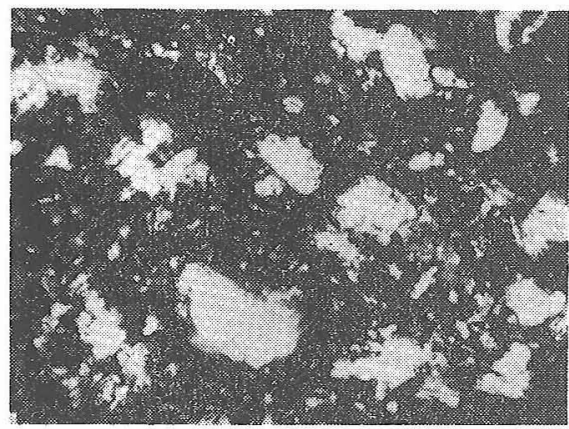

(b)

$1000^{\circ} \mathrm{C}$

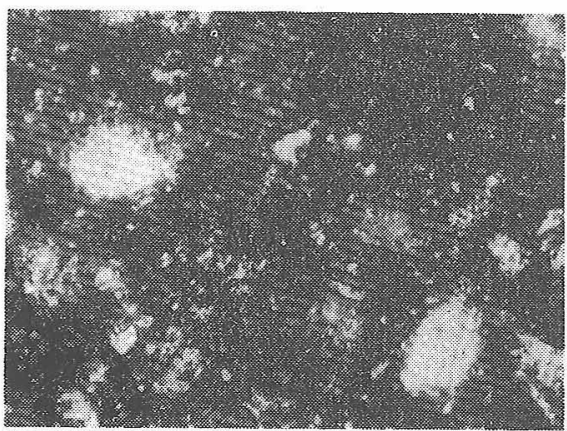

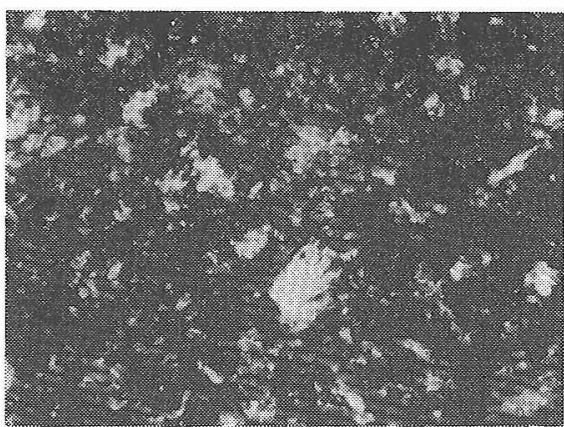

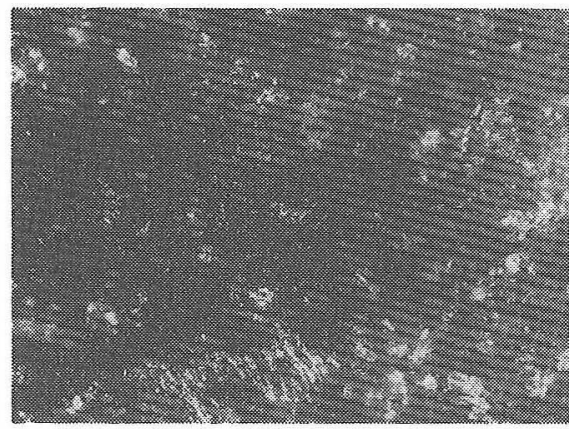

(e)

$1400^{\circ} \mathrm{C}$

Fig. 17. Polarizing microphotographs of fired bodies prepared from unground kaolin.

(crossed nicols; $\times 350$ )

なると非常に低くなり， $1200^{\circ} \mathrm{C}$ になるとほとんど等方 体となり，粒子马 $0.5 \mu$ 台の微粒子の集合となる. 粒界 などに生じていた低屈折率ガラス部分も幅が $0.5 \mu$ 台, 点在しているガラス粒子も $1 \mu$ くらいときくなる. 同 時に雲母鉱物の大部分む微粒子の集合状に変化し始める (図-17 (c))．この温度くらいになるとマトリックス中 に幅 1 くらいの曲りくねった形の, 後述する走查型電 子顕微鏡から亀裂と判定されたものが全体に認められる ようになる. 同種のものの分布の一例を図-19 (d) に示 す.

$1300^{\circ} \mathrm{C}$ になるとカオリン部分のガラスがさらに増加 し, また着色雲舟状鉱物も急に色が淡くなり，ガラス質 の中に相当によく発達したムライトが多数含まれている ものに変わる.このような部分にはときどき大きな気泡 ができている(図-17(d))、1350 C になるとカオリン部 分は低い複屈折を有する 1 位の微粒子が, 初めの集団 に支配されたような形の集合となり，ガラス相も極く少 量のようではあるが全体に連続相として分布している状 態となって，緻密化してくる. $1400^{\circ} \mathrm{C}$ になるとカオリ ン部分の微粒子は $1 \sim 3 \mu$ とやや大きくなり, 同時に複屈 折を幾分高く, 多分ムライトとして密に発達し, 低屈折 ガラスと共存することによって図-17（e）のように，\& やっとした外観を呈する集団状に発達してくる.

* 実際にはカオリン仮像であるが，初めカオリンであった部 分を簡単にカオリン部分と仮称することにする。 
カオリンの粉砕時間を長くすると，当然のことでは㐫 るが，特に粗粒子が減少し，組成鉱物が全体に細かくな る.図-18 (a).は $384 \mathrm{hrs}$ 粉砕したカオリン素地を 700 ${ }^{\circ} \mathrm{C}$ に焼成したもので，未粉碳の 図-17 (a) と比較する とよくわかる。しかし細かいカオリン部分については $700^{\circ} \mathrm{C}$ では大差ないように見える。しかし粉研時間の長 くなるほど，低屈折率ガラスの生成，亀裂の発生，むや っとした外観を呈するようになる温度などが，いずれも 低温度側にずれ，さらに高温度焼成されたものは素地が より均質な外観を呈するようになる（図-18）。
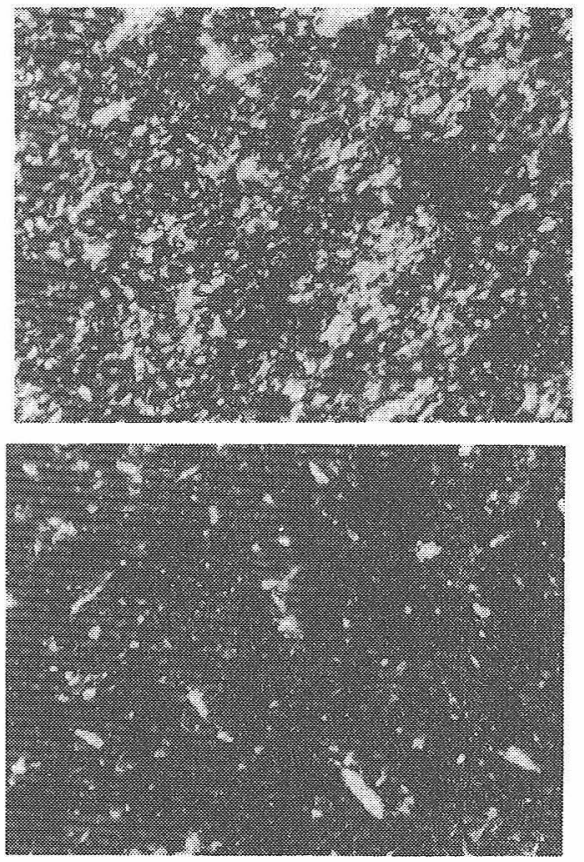

(b)

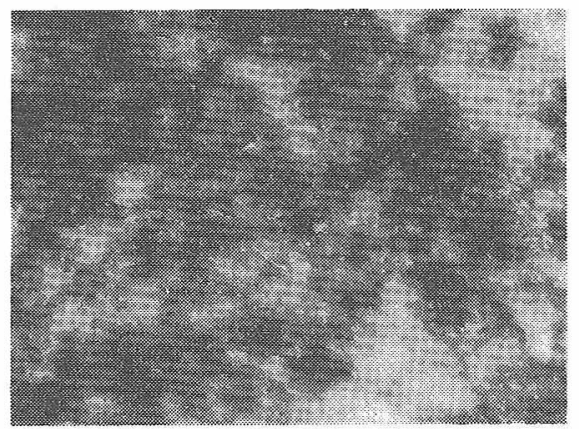

(c)

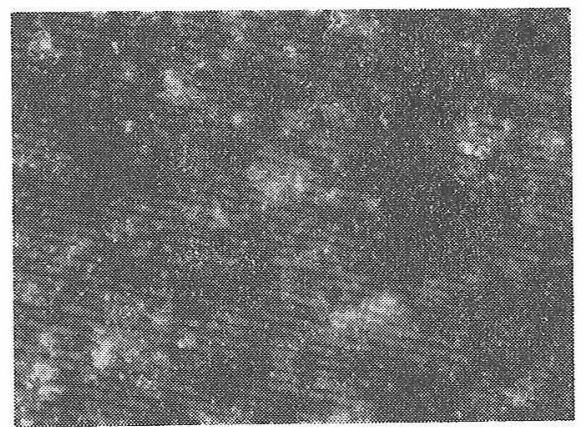

$1000^{\circ} \mathrm{C}$

$1200^{\circ} \mathrm{C}$

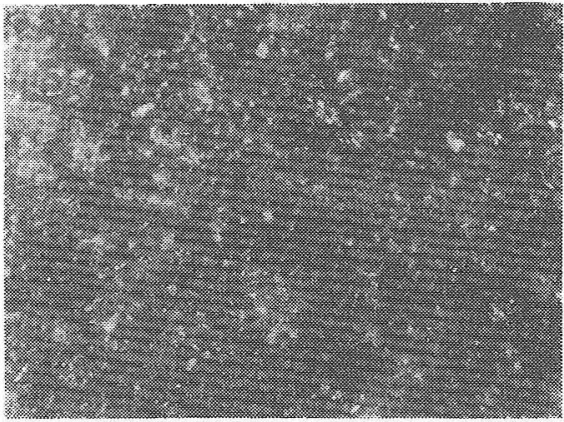

(e)

$1400^{\circ} \mathrm{C}$

Fig. 18. Polarizing microphotographs of fired bodies prepared from kaolin ground for $384 \mathrm{hrs}$.

(crossed nicols; $\times 350$ )

\section{2 走查型電子顕微鏡観察}

さらに組織的な変化を検討するため, 試験片の破面に ついて日立製作所製 HSM-2 型走査型電子顕微鏡による 2 次電子像の観察を行なった。図-20，21，22 はその一 部を示したものである.

図-20 は未粉砕カオリンの試験片についての写真であ るが，未焼成の試験片では，不規則な形状のカオリン集 合体と思われるものの粗な集団で，多数の空隚が含まれ

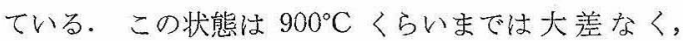
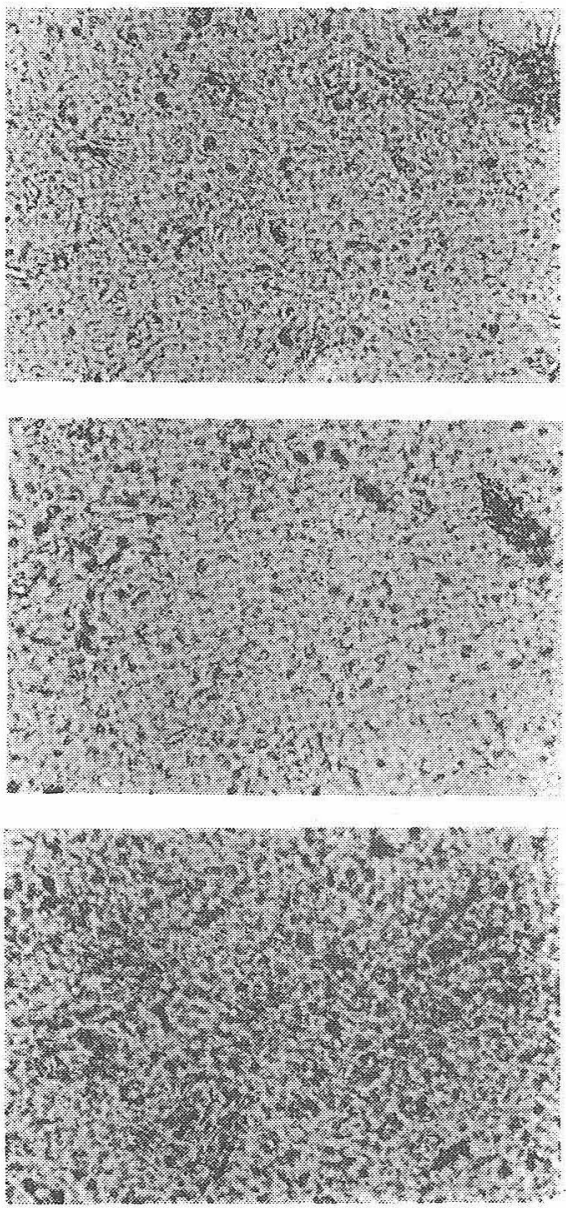

(b)

$1000^{\circ} \mathrm{C}$

$1100^{\circ} \mathrm{C}$

$1200^{\circ} \mathrm{C}$ 

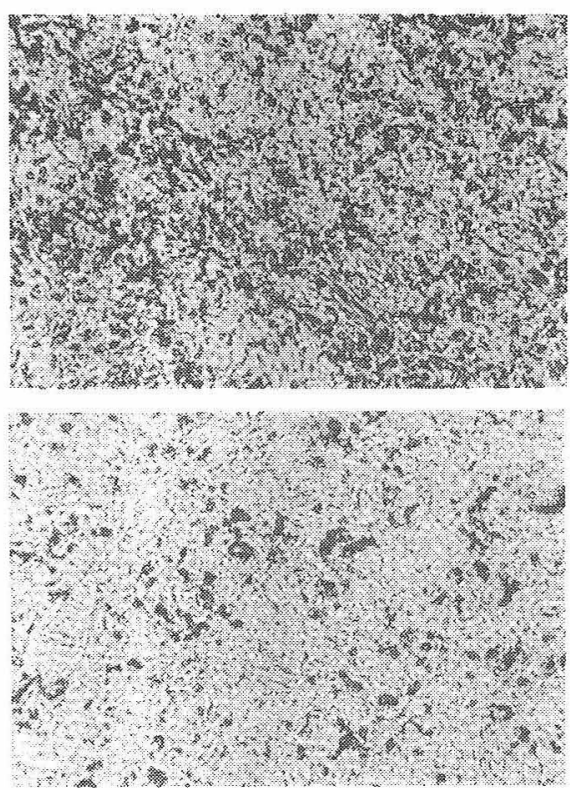

(e)

$1400^{\circ} \mathrm{C}$

Fig. 19. Folarizing microphotographs of fired bodies prepared from kaolin ground for $24 \mathrm{hrs}$.

(open nicol; $\times 350$ )

$1000^{\circ} \mathrm{C}$ になってもカオリン集団が細かいものになり， 粒子が互いに幾分焼き付いている感じを与えるくらいで ある、しかし $1100^{\circ} \mathrm{C}$ になるとカオリン集団自体が焼き 締って丸味を帯びたものとなると同時に，これらが互い に焼き付いて, 多分ガラス相の生成のため大きな集合体 を形成するようになり，今をでの空陌は相当に少なくな り緻密化するが，代って上記の集合体の境に幅の狭い不 規則に走った小さな刍裂芫生じ始める（図-20(c)）.

$1200^{\circ} \mathrm{C}$ になると焼き締りはさらに進み，大きな空隚 はほとえど認められなくなり，またカオリン部分は大き な緻密な集合体となり，この集合体と集合体の境に上記 の不規則な亀裂が多数入るようになる(図-20 (d)).

さらに焼成温度が高くなるとともにカオリン集合体は ますます維密になり，さらにこの集合体間も互いに焼き 付いて連統した形となり，その中に不規則な亀裂が全く とり込字れて残る状態となる。この亀裂も温度の上昇と ともに数が少なくなるが，同時に1つ1つの笔裂はやや 丸味を带びた幅も搪がった大きなものとなる（図一20(e， f)). 図-21 はこの龟裂部分を拡大したもので岕るが, 熔けたように炼を带びた形がよくわかる， $1400^{\circ} \mathrm{C} の$ 図-21 (b) では大きく拡がった亀裂の一部に幾分方向性 を持ってムライト結晶と思われるむのが多数発達してい るのが見られる。しかしその大きさ慨るしく小さく， 長さ $0.4 〜 1 \mu$ 位のようである.

図-22 は $384 \mathrm{hrs}$ 粉研したカオリンの試験片の写真で あるが，当然のことであるが，粒子や組織が全体に細か くなっている. 電子顕微鏡観察の結果加も，カオリン の粉砕時閒の長くなるほど変化が少しずつ低温度にずれ
ることが認められる．たとえば $384 \mathrm{hrs}$ 粉砕したカオリ ンでは $1000^{\circ} \mathrm{C}$ (図-22 (b)) ですでにカオリン集団の焼 き付きが進み，やや丸味を帯びた集合体となり，未粉砕 の場合の $1100^{\circ} \mathrm{C}$ に近い状態となり，またカオリン集合 体間の不規則な亀裂を $1200^{\circ} \mathrm{C}$ ですでに幅が拡がり丸味 のあるものになる。

$1350^{\circ} \mathrm{C}$ 以上になると末粉砕のものと相当に異なった 組織を示すように京る. $1350^{\circ} \mathrm{C}$ ですでに素地全体が全 く連続した均質なものとなり，その中に点々と，少数の むしろ丸味のある気孔が分布している状態となる。

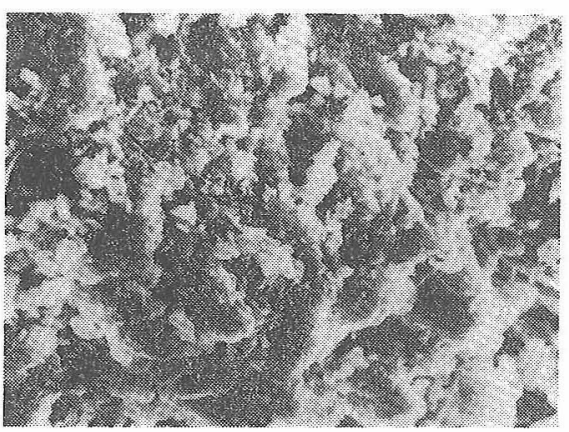

(a)

unfired

body

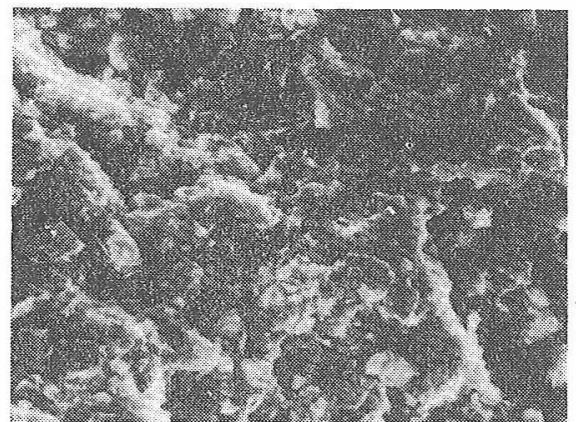

(b)

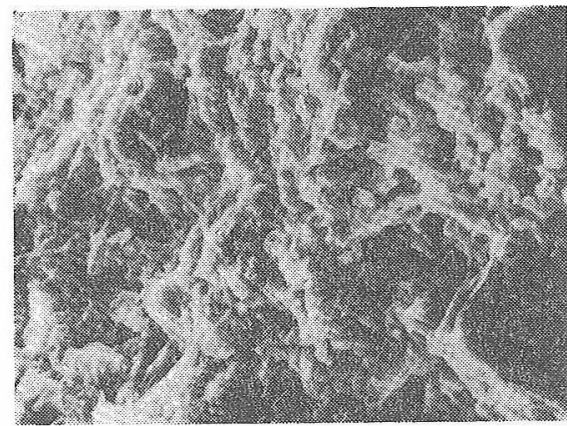

(c)

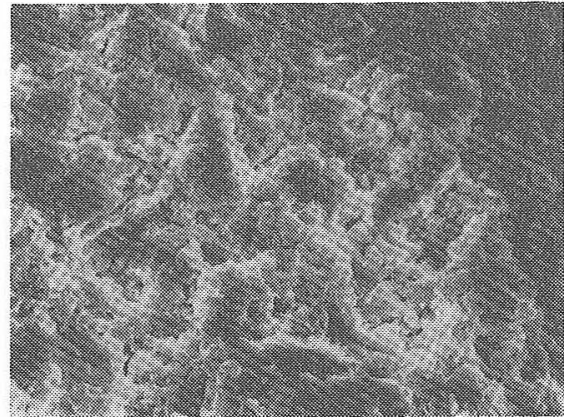




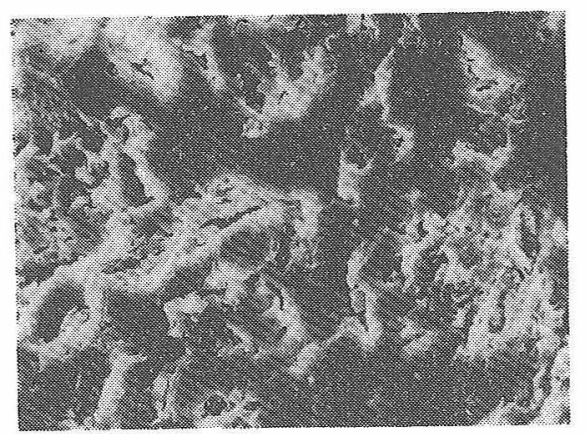

(e)

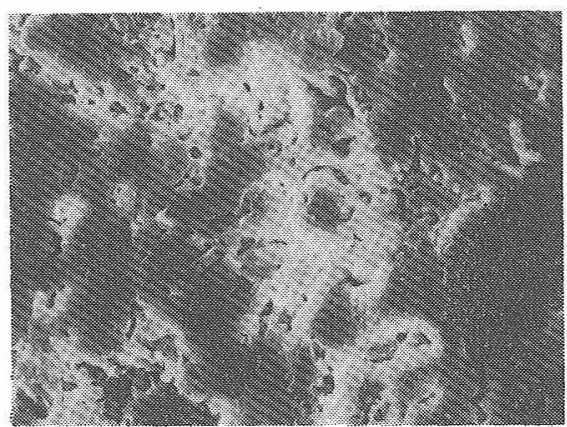

(f)

$1400^{\circ} \mathrm{C}$

Fig. 20. Scanning electron-microphotographs of fired bodies prepared unground kaolin. $(\times 700)$

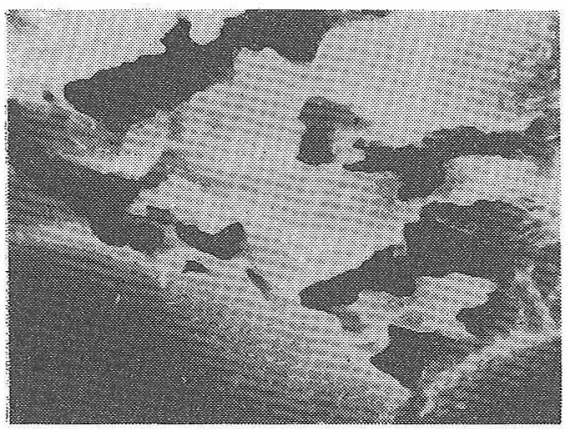

(a)

$1350^{\circ} \mathrm{C}$

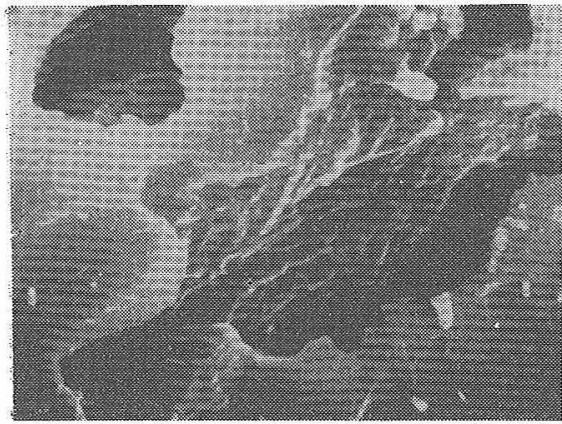

$1400^{\circ} \mathrm{C}$

Fig. 21. Scanning electron-microphotographs of fired bodies prepared from unground kaolin. $(x$ 7,000 )

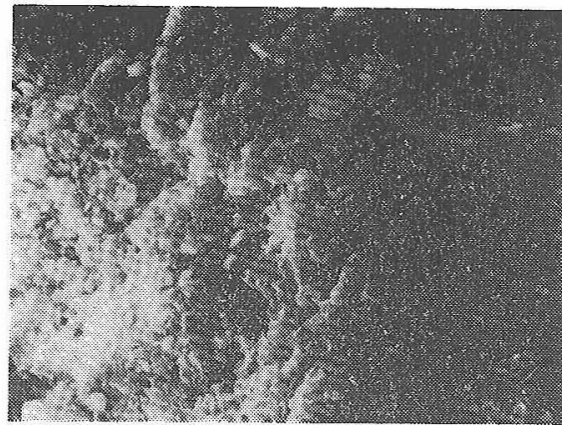

(a)

unfired

body

(b)

$1000^{\circ} \mathrm{C}$

(c)

$1100^{\circ} \mathrm{C}$

(d)

$1200^{\circ} \mathrm{C}$
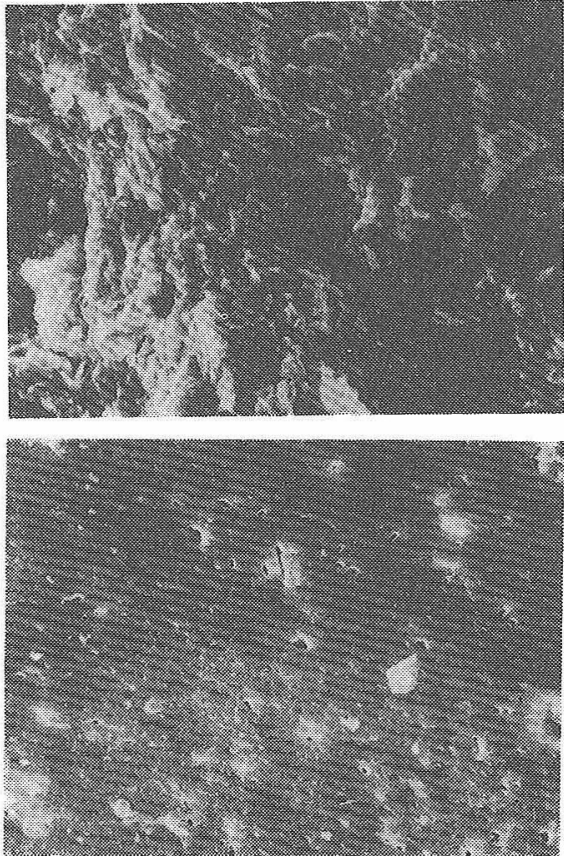

(e)

$1350^{\circ} \mathrm{C}$ 


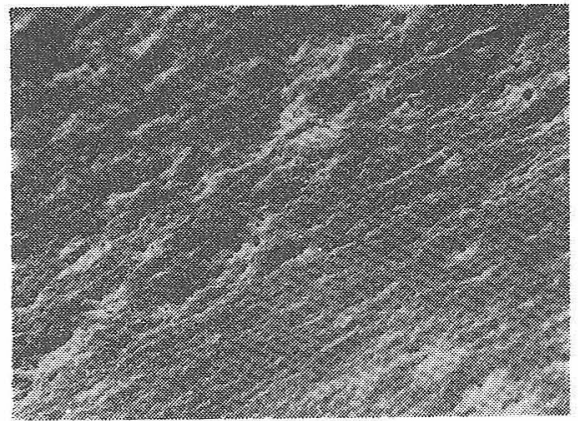

Fig. 22. Scanning electron-microphotographs of fired bodies from kaolin ground for $384 \mathrm{hrs}$. ( $x$ 700)

\section{7. 考察}

以上の測定，観察結果加ら，まず焼き締りの微構造的 な変化過程を総括してみると次のようになる。

このカオリン試料の成形試験片は数〜数十 則な形状のカオリン集団の集合状で，生状態では多数の 大きな空隙をともなっている。このよらな外観は力オリ ンの脱水過程でも見掛け上余り变化なく, 多分急速な収 縮と同時にカオリン部分が多孔質になる．X線的にはこ の過程でカオリンは無定形になるが，偏光顕微鏡下では 依然として複屈折を示し, それが温度の上昇とともに徐 々に低下するのみである。

$900^{\circ} \mathrm{C}$ になるとカオリン集団の粒界などに低屈折率部 分が生成し始めるが，X線的にはスピネル型中間相の生 成も始まる，その量は $1000^{\circ} \mathrm{C}$ になと相当量を占める ようになる。この温度になると電子顕微鏡下でも粒子間 の焼き付きがわずかに認められるようになり，さらに点 々と $0.5 \mu$ 位の極く小さなガラス粒子が生成し始める。 $1100^{\circ} \mathrm{C}$ になるとスピネル相は急に減少し，代ってクリ ストバライトが認められるようになり，同時にカオリン 仮像部分の複屈折も急に低下寸るとともに，急速に焼き 締った状態となって大きな集合体となる。これら集合体 の間には小さな刍裂が不規則に入り始めるようになる。

$1200^{\circ} \mathrm{C}$ になるとムライトも X 線的に認められるよう になるが，カオリン仮像は全く等方体となる。そしてこ の仮像の焼き締りは一段と進み，維密な集合体となり， 大きな空隙は認められなくなるが，小亀裂は多くなり， 同時にカオリン仮像粒子間の低屈折率ガラス 8 增加寸 る. $1300^{\circ} \mathrm{C}$ になるとガラス相はさらに増加し，力オリ ン仮像部分はますます緻密になって連続相を形成し，そ の中に亀裂は次第にとり込まれた状態となってくる。

$1350^{\circ} \mathrm{C}$ になると急にクリストバライトが減少し，同 時にガラス相自体も少量ではあるが連続相を形成するよ らになり，とり込まれた俥部分む次第に理められて形 も丸味を带び，数は減少してくる． $1400^{\circ} \mathrm{C}$ にるとタ リストバライトは全く認められなくなり，結晶相はムラ
イトのみとなる.このムライトは光学顕微鏡下でも認め られるくらいに発诖してくるが，その大きさは $0.4 \sim 1 \mu$ くらいのもので，多分初めのカオリン集団に支配された 形で，幾分方向性を示しながら集団をなして分布してい 子.

カオリンを粉䂗すると，特にカオリン集団の大きな塊 が細かくなる、そのため全体に均質な組織を示すように なるが，同時に低屈折率ガラスの生成し始める温度や夕 リストバライトの生成し始める温度，小さな龟裂が不規 則に入り始める温度など，全体の変化が幾分低温度にず れ，同時にクリストバライト生成量も増加する. $1350^{\circ} \mathrm{C}$ 以上になると微粉础したカオリン素地の均質性は特に著 るしくなり，全く䡒続した相の中に，点々と少数の小さ な丸味のある気孔が分布している状態となる。

この素地の組成鉱物の変化は，カオリンの加熱変化と して認められているものと大体一致している。 しかし夕 リストバライトが $1350^{\circ} \mathrm{C}$ で急激に減少し, $1400^{\circ} \mathrm{C}$ で認 められなくなる点功著るしく異なる。この温度は素地中 のガラスが連続相を形成し始める温度と一致しており， このカオリンが着色雲母鉱物や辰石などの不純物を含ん でいるため，高温度で熔融相を生成し，その中にクリス トバライトが愹け込むため減少するものと思われる.

このよらな微構造的な変化に対応して, 素地の緻密化 の変化はつぎのようになる。 カオリン萦地は $500^{\circ} \mathrm{C}$ 付 近からカオリンの脱水によると思われる顕著な収縮を起 こすが，これにつついて $900^{\circ} \mathrm{C}$ 付近からも急激な収縮 が起る.この収縮は，速度論的な検討から一応粒界拡散 と推定される拡散焼結にともなうものと思われる。この 焼結はメタカオリン粒子閒での固相焼結に刘応子る。こ の桩散焼結にともなら収縮に対しては，粉砕時閒の長い カオリンの方が，その過程に刘する見掛けの活性化エネ ルギー值が小さくなる.これは粉砕によってカオリン粒 子の構造が破壊され，粒子境界の拡散が容易になること によるものと推定される。

さらに $1100^{\circ} \mathrm{C}$ 付近，実際には $1020^{\circ} \mathrm{C}$ くらいから 3 回目の急激な収縮が起る。この収縮は同しく速度論的な 検討から粘性流動機構によるものと推定される。この温 度範囲はスピネル型中閻相のみの存在している範囲であ るが，この相中では多分拡散焼結も起っていると推定さ れるが，実際の素地ではこの温度ですでに相当量の熔融 物が生成していることがわかっている，粘性流動機構は 主としてこの熔融物に原因するものである. $900^{\circ} \mathrm{C}$ 付近 での拡散焼結による収縮は粉砕時閒の長いカオリンほど 起り易い。そのため $1100^{\circ} \mathrm{C}$ 付近の温度に達した段階で はより緻密な状態になっているため，これにつうくく粘性 流動的な䋊密化は比較的起りにくく，そのため，この過 程に対する活性化エネルギーは，長時間粉硴した場合ほ ど大きくなるものと思われる。しかし熔融物は粉砕時閒 
の長い方が低温度で生成し，その量も多いので， $1200^{\circ} \mathrm{C}$ 以上の高温度になると粉砕時間の長いカオリンの方が全 体の収縮が大きくなる。結局粉砕時間の長いカオリンの 方が低温度範囲での收縮が起り易く, $1100^{\circ} \mathrm{C}$ 付近の収 縮は起りにくくなるが, 高温度になると結果的には収縮 が大きくなるため, 全体に粉砕時間の長いカオリンほど 急速に収縮することになる。

カオリン相が互いに焼き付いて連続相を形成するよう になると素地の收縮は急に遅くなり，同時に亀裂状物も 中にとり达亲れた形になってくるため気孔率も急速に低 下してくる。粉砕時閒の長いカオリンほど低温度からこ のような状態になるため, 収縮もより低い温度から停止 し，見脚気孔率も0に付近くようになる。

このようにカオリン素地の焼き締り過程は, その微構 造的な変化によって相当によく説明することができるこ とがわかった。

\section{8. 総 括}

カオリン素地の焼き締り過程と, それにともなら微構 造変化を観察し，それらの相互関係を考察した。

まず素地の焼き締り状態を焼成収縮率，嵩比重，見掛 け気孔率の変化加ら概略検討した。その結果, $1000^{\circ} \mathrm{C}$ 以上の温度範囲で, 焼成温度とともに素地の焼き締りが 増大すること, カオリンを長時間粉砕すると $1000^{\circ} \mathrm{C}$ 焼 成の試験片の焼き締りは悪化するが， $1100^{\circ} \mathrm{C}$ 以上では 逆によくなることなどがわかった。

さらに速度論的な測定結果から，カオリン素地の収縮 は $500^{\circ} \mathrm{C}$ 付近, $900^{\circ} \mathrm{C}$ 付近, $1100^{\circ} \mathrm{C}$ 付近と 3 段階で 起ること, $900^{\circ} \mathrm{C}$ 付近の収縮は拡散過程によるもの, $1100^{\circ} \mathrm{C}$ 付近の収縮は主として粘性流動機構によるもの
と推定した。

さらに焼成試験片のX線回折, 偏光顕微鏡観察および 走査型電子顕微鏡による観察によって素地の微構造変化 を明らかにし，また焼き締り過程におけるいろいろな問 題が，これら微構造変化の観察結果によって相当によく 説明できることを明らかにした。

本研究の実施にあたって大倉和親記念財団の研究助成它得た ことを記し感謝の意安表します。また実験に使用した原料を御 提供下さった鳴海製陶（株）にも感謝申し上げます。さらに研 究の遂行にあたって種々御協力下さった本研究所助手烟野東一 氏, また研究室の皆さえ, 特に走査型電子顕微鏡の観察にあた っては助手秋山豊氏，顕微鏡用試料の作成にあたっては大塚正 氏の多大の助力它得たことを感謝します。

なお本研究の一部は昭和 45 年 4 月 22 日嘿業協会年会にお いて報告したものである。

\section{文献}

1) J.F. Hyslop, Trans. Brit. Ceram. Soc. $4 \hat{3}$ [3] 49 (1944).

2) E.B. Colegrave, G.R. Rigby, ibid. 51 [6] 355(1952).

3) J.E. Comeforo, R.B. Fischer, W.F. Bradley, J. Am. Ceram. Soc. 31 [9] 254 (1948).

4) R. Roy, D.M. Roy, E.E. Francis, ibid. 38 [6] 198 (1955).

5) H.M. Richardson, F.G. Wilde, Trans. Brit. Ceram. Soc. 51 [7] 387 (1952)

6) W.F. Bradley, R.E. Grim, Am. Mineral. 36 [3/4] 182 (1951)

7) G.W. Brindley, M. Nakahira, Nature, 181 [4619] 1333 (1958).

8) G.W. Brindley, M. Nakahira, J. Am. Ceram. Soc. 42 [7] 311 (1959).

9) 浜野健也, 東工大学術二ニ一ス, No. 37. p. 1 (Aug. 1967).

(7/12/1971 受付) 